\title{
Miranda
}

Revue pluridisciplinaire du monde anglophone /

Multidisciplinary peer-reviewed journal on the English-

speaking world

15 | 2017

Lolita at 60 / Staging American Bodies

\section{Donald Worster, Shrinking the Earth: The Rise and Decline of American Abundance}

Jean-Daniel Collomb

\section{OpenEdition}

\section{Journals}

\section{Electronic version}

URL: http://journals.openedition.org/miranda/10800

DOI: $10.4000 /$ miranda. 10800

ISSN: 2108-6559

Publisher

Université Toulouse - Jean Jaurès

\section{Electronic reference}

Jean-Daniel Collomb, "Donald Worster, Shrinking the Earth: The Rise and Decline of American Abundance", Miranda [Online], 15 | 2017, Online since 20 September 2017, connection on 16 February 2021. URL: http://journals.openedition.org/miranda/10800 ; DOI: https://doi.org/10.4000/miranda.10800

This text was automatically generated on 16 February 2021.

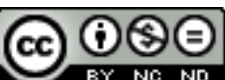

Miranda is licensed under a Creative Commons Attribution-NonCommercial-NoDerivatives 4.0 International License. 


\section{Donald Worster, Shrinking the Earth: The Rise and Decline of American Abundance} Jean-Daniel Collomb

\section{REFERENCES}

Worster, Donald, Shrinking the Earth: The Rise and Decline of American Abundance, New York, Oxford University Press, 2016, \$ 27.95, 265 p., ISBN 978-0-19-984495-1.

1 With Shrinking the Earth, Donald Worster makes yet another remarkable addition to an already long list of major books on US environmental history. The book is sure to be an engaging and instructive read for both environmental historians and readers not yet familiar with this branch of history. It is divided into three parts, each composed of three chapters and a concluding section titled 'Field Trip'.

In the prologue Worster lays out the main thesis of the book, which he calls the theory of the green light-a hint at F. Scott Fitzgerald's The Great Gatsby. In the novel Gatsby observes a green light on the horizon of the Long Island Sound and interprets it at first as a manifestation of America's unlimited natural potential, or "nature's green light of infinite promise" (4). By the end of the novel, however, he realizes that the green light is nothing but a chimera and is forced to come to terms with the natural limits of the New World. Worster uses Gatsby's tale of illusion and disappointment as a parable of American history from the early days of European settlement to the present time. According to this theory, the stupendous natural abundance that Europeans stumbled on when they discovered America around $1500 \mathrm{AD}$ was instrumental in kickstarting the modern age and, even more importantly, gave European settlers the false impression that there was no limit to what they could extract and expect from the natural world. As time went on, they found out that they would have to come to terms with the 
world's inescapable physical and biological limits. The goal of Worster's book is to put US history to the test of this theory.

3 Part I centers on the age of illusions brought about by the European discovery of American plenty. In Chapter 1, Worster emphasizes the deeply transformational impact of the discovery of the New World-the "Second Earth"- on the mindset of Europeans. Suddenly Europeans had access to what seemed to them like a world of unlimited abundance and opportunities. Worster concludes his chapter by an impressive summary of the radical demographic, economic, and environmental transformation of North America over the last five centuries. In the process he empathizes with sixteenth- and seventeenth-century settlers, thus staying clear of anachronistic selfrighteousness, one of the pitfalls of environmental history.

In chapter 2 Worster tries to shed light on the origins of Western ascendancy over the last five centuries. He approaches such transformational events as the scientific and industrial revolutions from the perspective of environmental history. Though by no means the only factor, the discovery of the Second Earth, Worster argues, was instrumental in stimulating empirical research and later supplied European industrialists with the overabundant resources they desperately needed. This leads Worster to fault his fellow historians for overemphasizing the influence of institutions and political ideologies to account for historical change while downplaying and sometimes ignoring the impact of natural forces. Although chapter 2 is a useful reminder of the relevance of environmental history, it may also lead the reader to overemphasize the importance of environmental factors: discovering vast amounts of natural resources is one thing but having the cultural, intellectual, and behavioral resources to make the most of them is another.

5 Chapter 3 strikes the first jarring note in the rise of American abundance by introducing some dissenting, albeit marginal, voices of restraint. It opens on a discussion of the way in which Adam Smith responded to the plentiful natural resources of the New World. Worster underscores the tension at the heart of The Wealth of Nations in which Smith conceives of the Second Earth as an unbelievable opportunity to fuel and expand economic growth while also acknowledging that, the world being finite, economic expansion would inevitably have to be replaced by "a comfortable stationary state" (46). Worster also points out the importance of physical limits in the thinking of such luminaries as David Ricardo and John Stuart Mill, and demonstrates that as early as the $18^{\text {th }}$ century some of the founding figures of modern economics were having second thoughts about the idea of unlimited growth. The reader familiar with Worster's Nature's Economy will recognize his wonderful knack for synthesizing complex ideas in a concise fashion without oversimplifying them.

6 Part I ends with a section in which Worster takes the island of Nantucket as an illustration of the book's main thesis. He calls Nantucket's history "a complicated parable of heroic achievement mixed with brutality and failure" (58), and recounts the tremendous expectations spawned by the whaling business in the $19^{\text {th }}$ century as well as its tremendous and heartrending environmental costs.

7 In part II, Worster chronicles the gradual and difficult emergence of environmental awareness in the United States and the slow recognition of nature's limits. Chapter 4, which deals with the early stage of US conservation, contains a profile of US writer and diplomat George Perkins Marsh, whose Man and Nature is rightly singled out as the foundational text of US conservation. Though instructive, this chapter is less original 
than the previous ones. It makes no notable additions to previous accounts of early conservationist efforts in the US given by Worster and other scholars.

Worster then moves on to the tremendous impact of the industrial revolution on American life, principally from the angle of energy production and consumption. This odyssey of energy production is environmental history at its best. Worster likens the environmental effects of the new industrial order to "a new Ice Age" (98) while also probing into the social impact of the quest for energy on the hill farmers of southern Appalachia and on Andrew Carnegie's workers in Pittsburgh.

Chapter 6 provides a fascinating insight into the ambivalent record of Theodore Roosevelt, America's first conservationist president. TR comes across as a man aware of the threat of resource scarcity but also steadfastly committed to unlimited economic expansion. His ambivalence sets the stage for a detailed analysis of federal conservation. The historical developments contained in the chapter have already been examined at length in such classics as Samuel Hays's Conservation and the Gospel of Efficiency. Nevertheless the chapter is well worth reading because the author delivers a sophisticated analysis of the ambivalent thrust behind federal conservation, the goals of which have been both to protect the natural world and enhance economic development. Worster makes the case that the Promethean roots of federal conservation have very often turned it into an instrument to ensure the continuation of unlimited economic growth by other means.

The field trip that concludes part II is set in California's Imperial Valley. Worster chronicles the epic efforts by the federal government to supply the Southwest with water. Readers already familiar with Marc Reisner's Cadillac Desert and Wortser's Rivers of Empire will learn nothing new. Finally Worster reflects on the potentially devastating repercussions of climate change and anticipates the return of the Colorado desert. One is struck by the wistful tone adopted by the historian, who seems comfortable with a deeply personal and heartfelt approach to the writing of environmental history.

11 The book's final part is evocatively titled "Planets of Limits". In chapter 7 Worster tackles the postwar boom and the advent of what historian Liz Cohen has dubbed the consumers' republic. This chapter is a reminder of the ambivalence of the postwar years as a rapidly expanding middle class made the most of a seemingly endless economic boom while critics of unlimited expansion like Rachel Carson and Paul Ehrlich managed to carve out unexpectedly large audiences for themselves.

Chapter 8 focuses exclusively on the Club of Rome's 1972 bestseller The Limits to Growth. It chronicles the somewhat irrational reception of the book when it was published. Particular attention is given to the knee-jerk reaction of many economists willing to preserve the dogma of unlimited growth on which their thinking was predicated. The chapter sounds like a defense of the Club of Rome against its many contemporary critics who often use it as a way to dismiss the warnings of environmentalists as unfounded apocalyptic rhetoric. Worster mentions the Green Revolution only in passing and gives this major historical development less than its due, especially in a discussion of the Club of Rome's legacy. Interestingly, he faults the authors of The Limits to Growth for not even contemplating the possibility that humans might be able to adjust in the face of growing limits, which leads them to promote an "irrationally gloomy worldview" (178). Although Worster's point seems well taken, he is himself very short on details about the human capacity for adaptation, which makes his objection sound more like an act of faith than a convincing argument. 
13 In Chapter 9, Worster contends that the ideological defeat of the Club of Rome may only be partial and temporary. He argues, quite persuasively, that environmental consciousness is now part and parcel of the American psyche, making unlimited growth a contentious issue in a way it never was before. The chapter then oscillates between guarded optimism and deep pessimism as the author discusses the alarming warnings of geophysicists. Judging from the gigantic scale of the environmental challenges facing humankind in the $21^{\text {st }}$ century and beyond, Worster's eventual plea for an earth ethic almost rings hollow.

14 In the book's final field trip, Worster tells the story of Canada's tar sand oil exploitation from early experiments at the beginning of the $20^{\text {th }}$ century to today's highly controversial industry. The book's brief epilogue is well worth reading if only because it contains the reflections of the greatest US environmental historian on humankind's future and the Anthropocene. Worster envisions the emergence of new social hierarchies as a consequence of the recognition of the limits of the earth. The very last paragraph of the book is a passionate plea in favor of environmental history. For the readers not yet familiar with it, Shrinking the Earth will be an inspiring starting point.

\section{INDEX}

Mots-clés: climat, croissance économique, écologie, environnement, environnementalisme, histoire environnementale, limites, révolution industrielle

Keywords: climate, ecology, economic growth, environment, environmental history, environmentalism, industrial revolution, limits

\section{AUTHORS}

\section{JEAN-DANIEL COLLOMB}

Maître de conférences

Université Jean Moulin (Lyon 3)

jean-daniel.collomb@univ-lyon3.fr 